\title{
Medical Society for the Study of Venereal Diseases
}

\section{The Royal Society of Medicine, 1 Wimpole Street, London W1M 8AE}

\author{
Honorary secretary's report to the 67th Annual General Meeting held on 28 October 1988
}

During the past year, 38 new members have been elected. Membership to date is 558,153 of whom live overseas. In the past year five honorary life members were elected, Dr T Moolhuysen, Dr JK Oates, Dr K Panikabutra, Dr CBS Schofield, and Dr A Siboulet. It is my sad duty to report the deaths of three of our honorary life members, Dr CD Alergant, Dr PLJ Sequeira, and Dr A Siboulet. At present there are 27 honorary life members, 19 of whom live in the United Kingdom. There is also one life member who subscribed before 1945 .

Six ordinary meetings were held during the year. The society is most grateful to OrthoCilag Pharmaceutical and to Merck Sharp and Dohme, who gave financial support for these meetings. We are indebted to the Royal Society of Medicine for enabling us to continue to hold our meetings here.

The spring meeting of the society was held at Cambridge on 30 June to 3 July 1988. Thirty three papers were presented including two by guest lecturers, Dr J Wallin (Sweden) and Dr H Hulsebosch (Netherlands), and 18 papers were shown as posters. Each year the standard rises. The meeting was well attended and much interesting discussion ensued. It was decided to institute an MSSVD spring meeting prize for the best paper. The winner was Dr R Gilson of the Middlesex Hospital, London. The Society is most grateful to Dr MR FitzGerald, our honorary assistant secretary, who did much to make the scientific and social events of the meeting so memorable and enjoyable. The society is grateful to all the pharmaceutical houses who contributed towards financing the spring meeting, in particular, Bayer UK, Smith Kline and French Laboratories, and Gist-Brocades Pharmaceuticals, who gave substantial amounts. All praise is due to our capable honorary treasurer, Dr JS Bingham, who has taken on the hard task of not only requesting funds from industry but also getting them. The society has been well rewarded. The president and the honorary secretary have visited the authorities at the University of Bordeaux II to make arrangements for the spring meeting to be held on 18 to 21 May 1989, which we hope members will support as it looks as though it will be a successful meeting.

The seventh genitourinary study weekend for junior doctors was held at Tetley Hall on 16 and 17 April 1988. Over 90 doctors attended. It was most encouraging to see a group of doctors from Scotland specialising in infectious diseases attending because of interest in disease related to human immunodeficiency virus (HIV). The society is indebted to Bayer UK who gave full financial support for the meeting. The next weekend will on 1 and 2 April 1989 and will again be at Leeds. Bayer UK has again promised full support.

The immediate past President, Dr J D Oriel, and the honorary secretary, Dr M A Waugh, together with the Royal Society of Medicine, organised the Anglo-Scandinavian Conference on Sexually Transmitted Diseases held on 11 to 13 May 1988. Over 200 delegates attended, and the conference proceedings have been published by the Royal Society of Medicine. The meeting was a great success, and we are indebted to Bayer UK and Gist-Brocades Pharmaceuticals who gave generous financial support. A similar meeting is planned at the Royal Society of Medicine 9 to 11 May 1990. It will be the 35th General Assembly of the International Union against the Venereal Diseases and the Treponematoses, the theme being "Sexually transmitted diseases in the world of AIDS".

Another new venture in 1989 will be an ordinary meeting of the society combined with our Dutch colleagues in Holland on 17 and 18 November 1989, the theme beito "Viral sexually transmitted diseases". This is to celebrate the 10th Anniversary of the Dutch Society for the Study of Sexuatt Transmitted Diseases.

The council of the society held six meef ings at which many items of interest to the specialty were discussed. Of particula importance were the future of a publication for the society, views on information aes confidentiality on HIV infection which wewe passed on to the General Medical Council through the president, Dr RN Thin, and Professor Michael Adler, and deliberation on the augmented compilation KC60 clini: returns.

During the summer recess, the Honoraci Secretary wrote offering all good wishes and support to the new National Venereolog Council of Australia, which has a new officaal publication, Venereology.

Genitourinary Medicine, volume 63 1987 , consisted of 430 pages and contained 81 original articles. During 1987,140 man $\overrightarrow{\mathrm{z}}$ scripts were submitted and the acceptang rate was $58 \%$. Dr GR Scott of Edinburgh Royal Infirmary is the new assistant edite and we are grateful for the continued onerous and diplomatic work of the editof Dr A McMillan.

An administrative change has been mate because of computerisation of records of members. In future would all members notify the honorary treasurer of any change of address, including the post code or similar for overseas members. Matters to do wi subscriptions are of course referred to him also.

Once again I should like to thank the othar officers of the society and my secretary, Mrs Joyce Horsbrough, who have lightened and facilitated my duties.

$M A$ Waug

Honorary Secretary, MSSV 